\title{
Effect of Plant Species, Fertilizer Acidity/Basicity, and Fertilizer Concentration on pH of Soilless Root Substrate
}

\author{
Ka Yeon Jeong \\ The Scotts Miracle-Gro Company, Marysville, OH 43041
}

Paul V. Nelson ${ }^{1}$

Department of Horticultural Science, North Carolina State University, Raleigh, NC 27695-7609

Carl E. Niedziela Jr.

Department of Biology, Elon University, Elon, NC 27244

\author{
David A. Dickey \\ Department of Statistics, North Carolina State University, Raleigh, NC \\ 27695-8203
}

Additional index words. alkalinity, electrical conductivity, root media

\begin{abstract}
The objective of this study was to determine how plant species, fertilizer potential acidity/basicity rating (PABR), and fertilizer concentration affect root substrate $\mathrm{pH}$. Three experiments were conducted. In the first experiment, 13 herbaceous species were grown in a root substrate of three sphagnum peatmoss: one perlite (v/v) with deionized water and a neutral fertilizer (NF) with a PABR of 0 for 78 days to determine species relationships to substrate $\mathrm{pH}$. The decrease in substrate $\mathrm{pH}$ ranged from 0.14 to 2.45 units, depending on species. In the second experiment, four of the 13 species from the previous trial representing the range of $\mathrm{pH}$ suppression were grown under similar growth conditions as the first experiment for 70 days. Substrate $\mathrm{pH}$ was lowered in the range of 0.47 to 2.72 units. In the third experiment, three fertilizers with PABRs of $150 \mathrm{~kg} \cdot \mathrm{t}^{-1} \mathrm{CaCO}_{3}$ equivalent alkalinity, 0 neutral, and $193 \mathrm{~kg} \cdot \mathrm{t}^{-1} \mathrm{CaCO}_{3}$ equivalent acidity were applied in a factorial design at 100 and $200 \mathrm{mg} \cdot \mathrm{L}^{-1} \mathrm{~N}$ at each irrigation to kalanchoe (the species with the greatest $\mathrm{pH}$ suppression from the previous experiments) for 56 days. When applied at the lower fertilizer rate $\left(100 \mathrm{mg} \cdot \mathrm{L}^{-1} \mathrm{~N}\right)$, the PABRs resulted in the final substrate $\mathrm{pH}$ levels of 4.68, 5.60, and 6.11 for the acidic fertilizer (AF), NF, and basic fertilizer (BF), respectively. At the high fertilizer rate $\left(200 \mathrm{mg} \cdot \mathrm{L}^{-1} \mathrm{~N}\right)$, substrate $\mathbf{p H}$ declined continuously to $3.97,4.03$, and 4.92 for the $\mathrm{AF}, \mathrm{NF}$, and $\mathrm{BF}$, respectively. Expression of PABR depended on the balance between the abiotic (chemical) effect of the fertilizers vs. the biotic (physiological) effects of the fertilizers on microbes and plants. The PABR was best expressed when the fertilizer supply was just adequate or lower indicating a closer connection to the biotic effect.
\end{abstract}

It is relatively easy to set the initial target $\mathrm{pH}$ of a root substrate by matching lime type and rate with the acidity of the substrate components. The challenge lies in maintaining this target $\mathrm{pH}$ throughout crop production. Factors that impact $\mathrm{pH}$ over time include irrigation water alkalinity (Bailey, 1996); residual content and properties of liming materials (Huang et al., 2010; Rippy

Received for publication 15 Aug. 2016. Accepted for publication 19 Oct. 2016.

This research was funded in part by a grant from USDA-ARS and by the North Carolina Agricultural Research Service (NCARS), Raleigh, NC.

Use of trade names does not imply endorsement by the NCARS of products named nor criticism of similar ones not mentioned.

${ }^{1}$ Corresponding author. E-mail: paul_nelson@ ncsu.edu. et al., 2007, 2016); acidification due to nitrification (Marschner, 1995); plant and microbe respiratory acidification (Marschner, 1995); acidic, neutral, or alkaline biotic effect of nutrient uptake (Pertusatti and Prado, 2007), which varies among plant species (Fisher et al., 2014a; Johnson et al., 2013); and the abiotic effect of fertilizer (Hignett, 1985).

There is interplay between fertilizer type and some of these $\mathrm{pH}$ controlling factors. Most fertilizer solutions have a low $\mathrm{pH}$, thus they are abiotically (chemically) acidic, even when they are biotically (physiologically) neutral or basic. When fertilizers supply ammonium, rhizosphere biotic acidification can occur during microbial nitrification of ammonium to nitrate, where two protons are generated for each ammonium ion oxidized. Plant and microbe uptake of ions supplied by fertilizers have yet another biotic effect on substrate $\mathrm{pH}$. During uptake of cationic nutrients, protons are released to the rhizosphere in exchange for uptake of positive cation charges (Havlin et al., 2014; Kafkafi, 2008; Marschner, 1995; Nelson, 2011; Zhu et al., 2009). Alkalinization occurs when microbes or plants take up protons along with anionic nutrients or release $\mathrm{OH}^{-}$or $\mathrm{HCO}_{3}{ }^{-}$to the rhizosphere in exchange for anionic nutrients (Pertusatti and Prado, 2007).

Plant species also interact with some of the factors controlling substrate $\mathrm{pH}$, namely respiration and proportion of cationic to anionic nutrient ions taken up. Release of $\mathrm{CO}_{2}$ by roots and rhizosphere microorganisms during respiration has an acidifying effect on the rhizosphere through the generation of carbonic acid (Marschner, 1995). Root respiration differs among plant species and with growth conditions (Taiz and Zeiger, 2010) and thus the potential for acidification of the substrate $\mathrm{pH}$ from the release of $\mathrm{CO}_{2}$ also varies across plant species. Plant species also differ in the proportions of ions extracted from the soil solution. Since nitrogen $(N)$ is the only nutrient that is plant available in both anion (nitrate) and cation (ammonium) forms and more $\mathrm{N}$ ions are typically taken up than other types combined (Taylor et al., 2010), the form of $\mathrm{N}$ taken up by plants has the largest effect on substrate $\mathrm{pH}$. Although the form of $\mathrm{N}$ taken up by plants is influenced to a degree by availability, plant species do vary in their affinity for ammoniacal vs. nitrate forms of N (von Wirén et al., 1997). Plants adapted to acid soils generally favor ammonium uptake, whereas those found in calcareous soils favor nitrate uptake (Marschner, 1995). As an example, ammonium uptake often predominates in blueberries (Hanson, 2006). A large differential effect of species on substrate $\mathrm{pH}$ during germination and early seedling growth was reported by Huang et al. (2001). Johnson et al. (2013) found a strong species effect on substrate $\mathrm{pH}$ when growing three bedding plant species for 4 weeks.

A PABR is included on the labels or technical sheets of greenhouse fertilizers. Pierre (1933) established the early procedures for this rating, which were later refined by the AOAC (1970, 1999) and described by Johnson et al. (2010, 2013). The PABR encompasses both biotic and abiotic impacts of fertilizer on substrate $\mathrm{pH}$. Although this rating system does not allow for effects of plant species, stage of maturity, or fertilizer concentration on substrate $\mathrm{pH}$, it is universally used today. In many situations, it adequately forecasts $\mathrm{pH}$ shifts. But there are other situations where it fails. The aberrant $\mathrm{pH}$ shifts are usually more acidic than predicted by PABR, suggesting involvement of the abiotic fertilizer effect. In this study, it was hypothesized that the unpredicted acidification is due to application of fertilizer in excess of that used by the plant and microbes. Production scenarios leading to excess fertilizer accumulation in the substrate can include the following: 1) quantity of fertilizer applied is higher than that recommended for the crop; 2) a single fertilizer program applied to multiple species that is 
designed to meet requirements of the faster growing species will result in excess application to the slower species; and 3) failure to reduce fertilizer application later in crop production when a plant's specific rate of growth and nutrient demand typically declines.

To test our hypothesis we 1) measured the differential effects of 13 plant species on substrate $\mathrm{pH}$ and 2) assessed the interactive effect of fertilizer concentration and PABR on substrate $\mathrm{pH}$ during plant growth.

\section{Materials and Methods}

General procedures. Three experiments were conducted in a glass greenhouse in Raleigh, NC, at $35^{\circ}$ north latitude. Greenhouse temperature set points for heating and cooling were 18 and $24{ }^{\circ} \mathrm{C}$, respectively. In all three experiments, the root substrate for propagation and subsequent experimentation consisted of $75 \%$ sphagnum peatmoss and $25 \%$ perlite by volume (Sun Gro Horticulture, Bellevue, WA). In Expt. 1, the root substrate was formulated with calcium carbonate powder at the rate of $65 \mathrm{~g} \cdot \mathrm{kg}^{-1}$ of peatmoss (dry weight basis). In Expts. 2 and 3 , the rate of calcium carbonate powder added to the substrate was adjusted to $60.1 \mathrm{~g} \cdot \mathrm{kg}^{-1}$ of peatmoss (dry weight basis) to avoid a high initial $\mathrm{pH}(>6.5)$ and gypsum $\left(\mathrm{CaSO}_{4}\right)$ was incorporated at $0.9 \mathrm{~g} \cdot \mathrm{L}^{-1}$ to maintain acceptable calcium levels. The substrates also contained a wetting agent (AquaGro 2000 G; Aquatrols, Paulsboro, NJ) at the label rate of $0.6 \mathrm{~g} \cdot \mathrm{L}^{-1}$. In the three experiments, all species were grown in $16.5-\mathrm{cm}$ top diameter, 1.8-L green, standard, plastic pots. Fertilizer treatments were applied with each irrigation to the top of each pot using a drip system supplied by sump-pumps (model 1A; Little Giant Pump Co., Oklahoma City, OK) in the bottom of opaque, plastic, 90-L tanks containing each single-strength fertilizer solution. Acidification was determined as the difference in substrate $\mathrm{pH}$ between the first and final measurements for each crop. The acidification level associated with each species was later categorized as minimal $(\Delta \mathrm{pH}<0.5)$, small $(\Delta \mathrm{pH}=0.50-0.99)$, moderate $(\Delta \mathrm{pH}=$ 1.00-1.49), and large $(\Delta \mathrm{pH} \geq 1.50)$.

Expt. 1: 13 species. Seeds of fibrous begonia (Begonia Xsemperflorens-cultorum Hort. 'Encore III Pink Bicolor'), impatiens (Impatiens walleriana Hook. F. 'Taboo Mix'), pansy (Viola ×wittrockiana Gams. 'Ultima Radiance Red'), petunia (Petunia ×hybrida Vilm. 'Petunia Easy Wave Blue'), sunflower (Helianthus annuus L. 'Ballad'), and vinca [Catharanthus roseus (L.) G. Don 'Pacifica XP Really Red'] were sown in 288-cell plug trays on 5 Nov. 2008. Tomato (Solanum esculentum L. 'Early Girl Hybrid') seeds were sown in 288-cell plug trays on 19 Nov. Cuttings of New Guinea impatiens (Impatiens hawkeri W. Bull 'Super Sonic White') and geranium (Pelargonium zonale L. 'Tango') were taken from stock plants and inserted into 51-cell trays on 18 Nov. Rooted cuttings of pot chrysanthemum [Dendranthema $\times$ grandiflora
(Ramat.) Kitam 'Kory'] and 51-cell tray liners of osteospermum [Osteospermum ecklonis (DC.) Norl. 'Astra White'], kalanchoe (Kalanchoe blossfeldiana Poelln. 'Kerinci'), and Rieger begonia (Begonia $\times$ hiemalis Fotsch 'Amstel Blitz') were obtained from commercial propagators. The following numbers of established plants were transplanted on 23 Dec. into each pot: one for geranium, New Guinea impatiens, Rieger begonia, sunflower, and tomato; two for impatiens, pansy, and petunia; three for begonia, kalanchoe, and vinca; four for osteospermum; and five for pot chrysanthemum. Incandescent light was applied to the chrysanthemum plants at an intensity of $2 \mu \mathrm{mol} \cdot \mathrm{m}^{-2} \cdot \mathrm{s}^{-1}$ for the first 2 weeks from 10:00 PM until 2:00 AM nightly to retard floral initiation after which plants were exposed to ambient short daylengths to induce flowering. During the 2 weeks of nightly light interruption, the chrysanthemum plants were isolated from the other species.

Plants were watered by species with deionized water from transplanting through the first day of substrate solution extraction [4 d after transplanting (DAT)], and then fertilized at each irrigation with a neutral water-soluble fertilizer $(17 \mathrm{~N}-2.2 \mathrm{P}-14.1 \mathrm{~K}$; Greencare $17 \mathrm{~N}-5 \mathrm{P}_{2} \mathrm{O}_{5}-17 \mathrm{~K}_{2} \mathrm{O}$, Kankakee, IL) dissolved in deionized water. In accordance with crop requirements, fertilizer solutions were applied at rates of $200 \mathrm{mg} \cdot \mathrm{L}^{-1} \mathrm{~N}$ for sunflower, pot chrysanthemum, and kalanchoe and $100 \mathrm{mg} \cdot \mathrm{L}^{-1} \mathrm{~N}$ for the other species.

Expt. 2: four species. On the basis of the results from Expt. 1, the same cultivars of fibrous begonia, New Guinea impatiens, Rieger begonia, and kalanchoe were selected to represent the minimal, small, moderate, and large acidification categories, respectively, as a validation of Expt. 1. Plants, propagated and handled in a similar manner to Expt. 1, were transplanted on 5 Apr. 2010. The fertilizer and number of plants were the same as Expt. 1. The fertilizer concentrations were also the same: $100 \mathrm{mg} \cdot \mathrm{L}^{-1} \mathrm{~N}$ for fibrous begonia, New Guinea impatiens, and Rieger begonia and $200 \mathrm{mg} \cdot \mathrm{L}^{-1} \mathrm{~N}$ for kalanchoe. All fertilization was started after the first measurement of substrate $\mathrm{pH}$ on 3 DAT.

Table 1. Results of statistical analysis of slice effects of plant species $\times$ days after transplanting (DAT) for $\mathrm{pH}$ data in Expts. 1 and 2 and fertilizer type $\times$ concentration $\times$ DAT for electrical conductivity $(\mathrm{EC})$ and pH data in Expt. 3.

\begin{tabular}{|c|c|c|c|c|c|c|c|c|c|c|}
\hline \multicolumn{3}{|c|}{ Expt. 1} & \multicolumn{3}{|c|}{ Expt. 2} & \multicolumn{5}{|c|}{ Expt. 3} \\
\hline \multicolumn{3}{|c|}{ Species $\times$ DAT } & \multicolumn{3}{|c|}{ Species $\times$ DAT } & \multicolumn{5}{|c|}{ Fertilizer type $\times$ concn $\times$ DAT } \\
\hline \multicolumn{3}{|c|}{$\mathrm{pH}$} & \multicolumn{3}{|c|}{$\mathrm{pH}$} & \multicolumn{3}{|c|}{$\mathrm{EC}$} & \multicolumn{2}{|c|}{$\mathrm{pH}$} \\
\hline DAT & $F$ value & $\operatorname{Pr}>F$ & $\overline{\mathrm{DAT}}$ & $F$ value & $\overline{\operatorname{Pr}>F}$ & $\overline{\mathrm{DAT}}$ & $F$ value & $\operatorname{Pr}>F$ & $F$ value & $\operatorname{Pr}>F$ \\
\hline$\overline{4}$ & 6.82 & $<0.0001$ & 3 & 1.92 & 0.1306 & 7 & 8.39 & $<0.0001$ & 4.95 & 0.0004 \\
\hline 14 & 2.27 & 0.0091 & 7 & 2.64 & 0.0525 & 14 & 27.64 & $<0.0001$ & 5.13 & 0.0003 \\
\hline 25 & 2.16 & 0.0136 & 14 & 3.61 & 0.0153 & 21 & 51.24 & $<0.0001$ & 9.83 & $<0.0001$ \\
\hline 39 & 11.49 & $<0.0001$ & 21 & 5.64 & 0.0012 & 28 & 112.08 & $<0.0001$ & 23.50 & $<0.0001$ \\
\hline 57 & 44.60 & $<0.0001$ & 28 & 13.61 & $<0.0001$ & 35 & 140.30 & $<0.0001$ & 25.62 & $<0.0001$ \\
\hline \multirow[t]{6}{*}{78} & 58.85 & $<0.0001$ & 35 & 39.00 & $<0.0001$ & 42 & 236.83 & $<0.0001$ & 81.00 & $<0.0001$ \\
\hline & & & 42 & 57.94 & $<0.0001$ & 49 & 272.74 & $<0.0001$ & 114.12 & $<0.0001$ \\
\hline & & & 49 & 92.94 & $<0.0001$ & 56 & 261.74 & $<0.0001$ & 157.15 & $<0.0001$ \\
\hline & & & 56 & 113.11 & $<0.0001$ & & & & & \\
\hline & & & 63 & 50.00 & $<0.0001$ & & & & & \\
\hline & & & 70 & 35.26 & $<0.0001$ & & & & & \\
\hline
\end{tabular}

Expt. 3: fertilizer type-concentration. This experiment was conducted concurrently with Expt. 2. The three commercial water-soluble fertilizers (Greencare, Kankakee, IL) used were an AF, 20N-4.4P-16.6K, with a potential acidity of $193 \mathrm{~kg} \cdot \mathrm{t}^{-1} \mathrm{CaCO}_{3}$ equivalent; the same NF used in Expts. 1 and $2,17 \mathrm{~N}-2.2 \mathrm{P}-14.1 \mathrm{~K}$, with 0 potential acidity/ basicity; and a $\mathrm{BF}, 13 \mathrm{~N}-0.88 \mathrm{P}-10.8 \mathrm{~K}$, with a potential basicity of $150 \mathrm{~kg} \cdot \mathrm{t}^{-1} \mathrm{CaCO}_{3}$ equivalent. The percentages by weight of fertilizer in the ammoniacal nitrogen $\left(\mathrm{NH}_{4}^{+}-\mathrm{N}\right)$ form were $8.0 \%, 4.2 \%$, and $0.6 \%$, whereas nitrate nitrogen $\left(\mathrm{NO}_{3}{ }^{-} \mathrm{N}\right)$ percentages were $12.0 \%, 12.8 \%$, and $12.4 \%$ for $\mathrm{AF}, \mathrm{NF}$, and $\mathrm{BF}$, respectively. The AF, NF, and BF were dissolved in deionized water $(18 \mathrm{M} \Omega)$ at concentrations of 100 and $200 \mathrm{mg} \cdot \mathrm{L}^{-1} \mathrm{~N}$. Rooted cuttings of kalanchoe 'Kerinci', propagated and handled in a similar manner to Expts. 1 and 2, were transplanted on 5 Apr. 2010. Plants were irrigated with deionized water until 7 DAT when fertilizer treatments were initiated and applied at each irrigation thereafter.

Data collection. Substrate $\mathrm{pH}$ in all three experiments and electrical conductivity (EC) in Expt. 3 were measured periodically in substrate solutions extracted with a Rhizon soil-moisture sampler (Soilmoisture Equipment Corp., Santa Barbara, CA) consisting of a porous polymer tube $(10 \mathrm{~cm}$ length $\times 2.5 \mathrm{~mm}$ diameter). One sampler was placed diagonally in each pot by inserting the sampler at a $45^{\circ}$ angle from the top to the bottom of the root substrate. Substrate solution was extracted $1 \mathrm{~h}$ after each fertilizer application by connecting the sampler to a sample vial and applying a vacuum.

Substrate $\mathrm{pH}$ and EC were measured using a Model $695 \mathrm{pH} /$ conductivity meter (Extech Instruments, Waltham, MA). The $\mathrm{pH}$ electrode was standardized with $\mathrm{pH} 4$ and 7 buffer solution for every five sample measurements. The change $(\Delta)$ in $\mathrm{pH}$ (all three experiments) and EC (Expt. 3 only) were determined as the difference between initial and final substrate levels determined by subtracting levels on the first day of fertilizer application from corresponding values on the last day of application. These pairs of DAT 
for Expts. 1, 2, and 3 were 4 and 78, 3 and 70, and 7 and 56, respectively.

Experimental designs and statistical analysis. Expt. 1 was arranged in a randomized complete block with 13 species and five blocks. The $\mathrm{pH}$ was measured as repeated samples on 6 dates for a total of 390 measurements on 65 experimental units. Expt. 2 was also a randomized complete block with four species and five blocks. The $\mathrm{pH}$ was measured as repeated samples on 11 dates for a total of 220 measurements on 20 experimental units. Expt. 3 was a two-way factorial design with three fertilizer acidity-basicity types (acid, neutral, basic) and two fertilizer concentrations (100 and $200 \mathrm{mg} \cdot \mathrm{L}^{-1} \mathrm{~N}$ ) for a total of six treatment combinations arranged in five blocks sampled on eight repeated dates (240 measurements on 30 experimental units). Each experimental unit consisted of two pots in all three experiments.

Analyses were done in SAS using PROC ANOVA, PROC GLM, and PROC MIXED for inference. Treatments were the individual species in Expts. 1 and 2 and fertilizer typeconcentration combinations in Expt. 3. All three experiments included variance components for rep and rep $\times$ treatment and a repeated measures structure for the measurements within each experimental unit. Kenward Roger df were used for inference. Analyzing the experiments as a whole allowed testing for differences in lsmeans of treatments within each day using a slice option for the lsmeans. The slice option enabled detection of any trends in the strength of evidence ( $F$ value) for treatment separation over time. For the polynomial analyses, the data set was divided into subsets by treatment. Reported $R^{2}$ for the graphs and tests of significance were computed using a model with rep and polynomial effects on the treatment subsets. The curve coefficients were computed on those same subsets using simple polynomial regressions. The $\Delta \mathrm{pH}$ data were analyzed using analysis of variance (ANOVA) by PROC ANOVA. Means and standard errors were calculated for all of the sample dates by treatment combinations using PROC MEANS.

\section{Results and Discussion}

Species effects. There were significant differences in substrate $\mathrm{pH}$ due to the twoway interaction of species by sample date in both Expts. 1 and 2. The slice option of PROC MIXED in Expt. 1 showed that for each measurement date, from 25 DAT on, the species had strongly significantly different responses with monotonically stronger statistical significance on each subsequent measurement date (Table 1). This indicated a strong divergence between species (Fig. 1). The slice option of PROC MIXED in Expt. 2 showed that for each measurement date, from 3 until 56 DAT, the species had strongly significantly different responses with monotonically stronger statistical significance on each subsequent measurement date until the trend reversed and $F$ values decreased on 63 and 70 DAT (Table 1). This
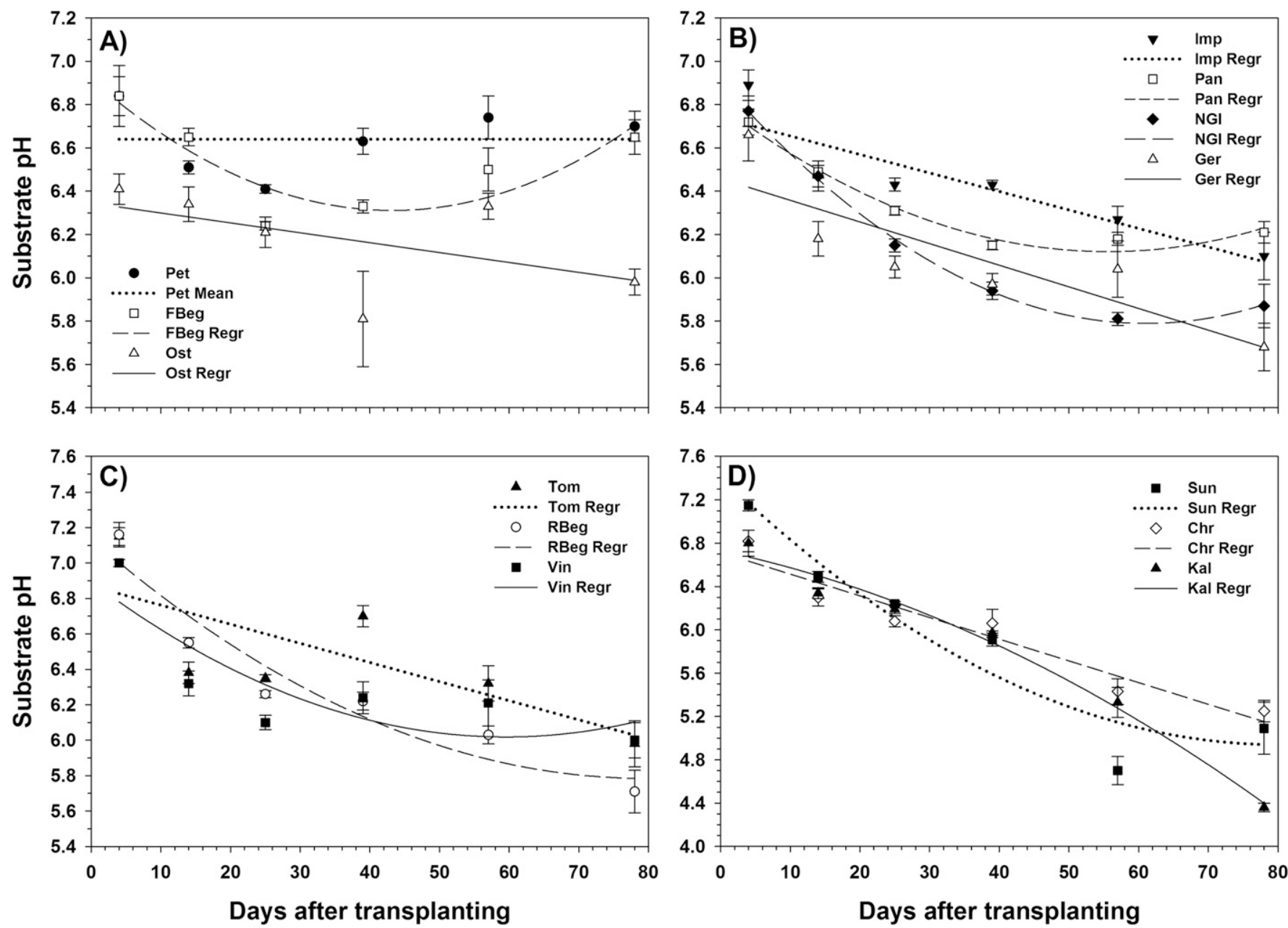

Fig. 1. Mean root substrate $\mathrm{pH}$ levels measured from 4 to $78 \mathrm{~d}$ after transplanting for 13 plant species fertilized at each irrigation with a neutral, water-soluble fertilizer (17N-2.2P-14.1K) in Expt. 1. Petunia (Pet), fibrous begonia (FBeg), osteospermum (Ost), impatiens (Imp), pansy (Pan), New Guinea impatiens (NGI), geranium (Ger), tomato (Tom), Rieger begonia (RBeg), and vinca (Vin) were fertigated at $100 \mathrm{mg} \cdot \mathrm{L}^{-1} \mathrm{~N}$; whereas sunflower (Sun), chrysanthemum (Chr), and kalanchoe (Kal) were fertigated at $200 \mathrm{mg} \cdot \mathrm{L}^{-1} \mathrm{~N}$. The 13 species were grouped in these graphs by mean change in $\mathrm{pH}(\Delta \mathrm{pH})$ from initial to final measurement as $(\mathbf{A})$ minimal $(\Delta \mathrm{pH}<0.50)$, (B) small $(\Delta \mathrm{pH}=0.50-0.99),(\mathbf{C})$ medium $(\Delta \mathrm{pH}=1.00-1.49)$, and (D) large $(\Delta \mathrm{pH}=1.5-2.49)$ acidifier species. The regression (Regr) equations generated for the best fit models were (A) $y_{\mathrm{Pet}}=6.64, y_{\mathrm{FBeg}}=6.91-0.0279 x+0.000323 x^{2}\left(r^{2}=0.67\right)$, and $y_{\mathrm{Ost}}=6.34-0.00463 x\left(r^{2}=0.21\right) ;(\mathbf{B}) y_{\mathrm{Imp}}=6.74-$ $0.00858 x\left(r^{2}=0.64\right), y_{\mathrm{Pan}}=6.80-0.0248 x+0.000224 x^{2}\left(r^{2}=0.86\right), y_{\mathrm{NGI}}=6.91-0.0367 x+0.000302 x^{2}\left(r^{2}=0.91\right)$, and $y_{\mathrm{Ger}}=6.46-0.00996 x\left(r^{2}=0.59\right)$; (C) $y_{\mathrm{Tom}}=6.87-0.0109 x\left(r^{2}=0.49\right), y_{\mathrm{RBeg}}=7.14-0.0343 x+0.000218 x^{2}\left(r^{2}=0.87\right)$, and $y_{\mathrm{Vin}}=6.90-0.0295 x+0.000248 x^{2}\left(r^{2}=0.56\right)$; and $(\mathbf{D}) y_{\mathrm{Sun}}=$ $7.41-0.0616 x+0.000384 x^{2}\left(r^{2}=0.86\right), y_{\mathrm{Chr}}=6.71-0.0199 x\left(r^{2}=0.86\right)$, and $y_{\mathrm{Kal}}=6.73-0.0137 x-0.000208 x^{2}\left(r^{2}=0.95\right)$. Bars indicate $\pm \mathrm{SE}(\mathrm{n}=5)$. 
indicated a strong divergence between species during most of Expt. 2 (Fig. 2). However, the regression analysis of the petunia data in Expt. 1 was not significant indicating there were no differences among data points. The mean $\mathrm{pH}$ for petunia was 6.64. Regression analysis for linear, quadratic, or both models were significant for all other species with the best fit provided in Figs. 1 and 2 for Expts. 1 and 2, respectively.

Resulting $\Delta \mathrm{pH}$ values for Expts. 1 and 2 were significant (Table 2). In Expt. 1, the 13 species were categorized into four groups according to their associated acidification level, as defined in the Materials and Methods. Petunia $(\Delta \mathrm{pH}=-0.14)$, fibrous begonia $(-0.19)$, and osteospermum $(-0.43)$ were in the minimal acidification category $(\Delta \mathrm{pH}<0.50)$ (Fig. 1A). Pansy $(\Delta \mathrm{pH}=$ $-0.51)$, impatiens $(-0.79)$, New Guinea impatiens $(-0.89)$, and geranium $(-0.97)$ were in the small acidification category $(\Delta \mathrm{pH}=$ 0.50-0.99) (Fig. 1B). Vinca $(\Delta \mathrm{pH}=-1.00)$, tomato $(-1.17)$, and Rieger begonia $(-1.46)$ were in the moderate acidification category $(\Delta \mathrm{pH}=1.00-1.49)$ (Fig. 1C). Pot chrysanthemum $(\Delta \mathrm{pH}=-1.56)$, sunflower $(-2.44)$, and kalanchoe $(-2.45)$ were in the large acidification category $(\Delta \mathrm{pH} \geq 1.50)$ (Fig. 1D). In Expt. 2, the $\Delta \mathrm{pH}$ values for fibrous begonia, New Guinea impatiens, Rieger begonia, and kalanchoe were -0.47 , $-0.69,-1.05$, and -2.72 , respectively (Table 2). The moderate shifts in $\Delta \mathrm{pH}$ values in Expt. 2 compared with those from Expt. 1 may have been caused by the intentionally lower initial substrate $\mathrm{pH}$ (less lime in the substrate), shorter growth period (70 d compared with $78 \mathrm{~d}$ in Expt. 1), and winter growing season in Expt. 1 vs. spring season in Expt. 2 (Table 2). However, species fell into the same acidification categories in both experiments. Similarly, Argo (1996) found that the substrate $\mathrm{pH}$ levels of pansy and petunia were the highest, whereas geranium was the lowest among nine bedding plant species 4 weeks after planting when all plants were grown under the same system. Although different cultivars were tested in our study than Argo's study, species effects on $\mathrm{pH}$ were in the same order in both studies.

Although the PABR of the fertilizer applied in Expts. 1 and 2 was 0 (neutral), this neutral impact on root substrate would only apply during plant uptake. The fertilizer solutions alone had acid $\mathrm{pH}$ levels of 5.02 and 4.55 at 100 and $200 \mathrm{mg} \cdot \mathrm{L}^{-1} \mathrm{~N}$, respectively. Therefore, the acidic abiotic effect of fertilizer on substrate $\mathrm{pH}$ was expected to predominate during a period of early growth, whereas the neutral biotic effect of fertilizer on substrate $\mathrm{pH}$ was anticipated during a later period of larger biomass. This transition was seen in Expt. 2 in the resulting substrate $\mathrm{pH}$ curves for the three species fertilized at the lower concentration (Fig. 2). The larger decline in $\mathrm{pH}$ for kalanchoe could have been partly due to slower growth occurring in the reproductive stage, but more likely to aboveadequate fertilizer application since the decline in $\mathrm{pH}$ was continuous during the entire

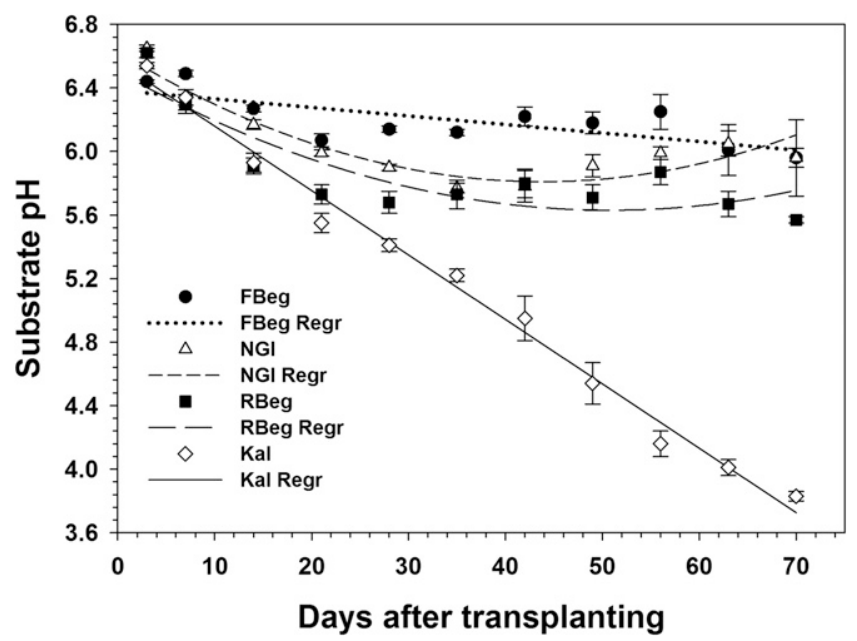

Fig. 2. Mean root substrate $\mathrm{pH}$ levels measured from 3 to $70 \mathrm{~d}$ after transplanting for four plant species fertilized at each irrigation with a neutral, water-soluble fertilizer $(17 \mathrm{~N}-2.2 \mathrm{P}-14.1 \mathrm{~K})$ in Expt. 2. Fibrous begonia (FBeg), New Guinea impatiens (NGI), and Rieger begonia (RBeg) were fertigated at $100 \mathrm{mg} \cdot \mathrm{L}^{-1} \mathrm{~N}$; whereas kalanchoe (Kal) were fertigated at $200 \mathrm{mg} \cdot \mathrm{L}^{-1} \mathrm{~N}$. The regression (Regr) equations generated for the best fit models were $y_{\mathrm{FBeg}}=6.38-0.00527 x\left(r^{2}=0.42\right), y_{\mathrm{NGI}}=6.63-$ $0.0376 x+0.000430 x^{2}\left(r^{2}=0.81\right), y_{\mathrm{RBeg}}=6.50-0.0345 x+0.000340 x^{2}\left(r^{2}=0.68\right)$, and $y_{\mathrm{Kal}}=6.56-$ $0.0406 x\left(r^{2}=0.98\right)$. Bars indicate \pm SE $(\mathrm{n}=5)$.

crop. Argo et al. (1997) found a decline in substrate $\mathrm{pH}$ due to increasing fertilizer concentration with nine pot plant species. Therefore, our low substrate $\mathrm{pH}$ levels of pot chrysanthemum, sunflower, and kalanchoe may be due to high fertilizer concentration as well as species effects. This prompted the third experiment with kalanchoe, the species with the greatest decline in $\mathrm{pH}$.

Fertilizer-type-concentration effects. All fertilizer solutions applied in Expt. 3 had an acidic $\mathrm{pH}$. At a concentration of $100 \mathrm{mg} \cdot \mathrm{L}^{-1} \mathrm{~N}$, the average $\mathrm{pH}$ level of AF (AF100), NF (NF100), and BF (BF100) solutions were $6.07 \pm 0.11,5.02 \pm 0.06$, and $6.19 \pm 0.08$, respectively, whereas at a concentration of 200 $\mathrm{mg} \cdot \mathrm{L}^{-1} \mathrm{~N}$ the $\mathrm{pH}$ of AF (AF200), NF (NF200), and $\mathrm{BF}(\mathrm{BF} 200)$ solutions were $6.02 \pm 0.08$, $4.55 \pm 0.14$, and $5.82 \pm 0.06$, respectively. The $\mathrm{NF}$ solution was the most acidic among the three types of fertilizers at both concentrations. The average EC of the AF100, NF100, and BF100 solutions were $0.79 \pm 0.03,0.75 \pm 0.02$, and $0.86 \pm 0.01 \mathrm{dS} \cdot \mathrm{m}^{-1}$, respectively, and the average EC of the AF200, NF200, and BF200 solutions were $1.53 \pm 0.05,1.39 \pm 0.03$, and $1.65 \pm 0.03$, respectively.

There were significant differences in both substrate $\mathrm{EC}$ and $\mathrm{pH}$ due to the threeway interaction of fertilizer type by concentration by sample date in Expt. 3 (Fig. 3). The slice option of PROC MIXED on the EC data in Expt. 3 demonstrated that for each measurement date from 7 DAT onwards, the species showed strongly significantly different responses with monotonically stronger statistical significance on each subsequent measurement date until the last date (56 DAT), which had an $F$ value slightly lower than the previous date (49 DAT) (Table 1). This indicated a strong divergence between the fertilizer type-concentration treatments throughout most of the experiment (Fig. 3B). The slice option of PROC MIXED on the
Table 2. Change $(\Delta)$ in mean root substrate $\mathrm{pH}$ of 13 plant species from 4 to $78 \mathrm{~d}$ after transplanting (DAT) in Expt. 1 and four plant species from 3 to 70 DAT in Expt. 2. ${ }^{\mathrm{z}}$

\begin{tabular}{|c|c|c|}
\hline \multirow[b]{2}{*}{ Species } & Expt. 1 & Expt. 2 \\
\hline & \multicolumn{2}{|c|}{$\Delta \mathrm{pH}$} \\
\hline Petunia & -0.14 & - \\
\hline Fibrous begonia & -0.19 & -0.47 \\
\hline Osteospermum & -0.44 & - \\
\hline Pansy & -0.51 & - \\
\hline Impatiens & -0.79 & - \\
\hline New Guinea impatiens & -0.89 & -0.69 \\
\hline Geranium & -0.97 & - \\
\hline Vinca & -1.01 & - \\
\hline Tomato & -1.18 & - \\
\hline Rieger begonia & -1.46 & -1.05 \\
\hline Chrysanthemum & -1.56 & - \\
\hline Sunflower & -2.06 & - \\
\hline Kalanchoe & -2.45 & -2.72 \\
\hline $\operatorname{LSD}_{0.05}$ & 0.39 & 0.30 \\
\hline
\end{tabular}

LSD $=$ least significant difference.

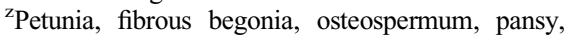
impatiens, New Guinea impatiens, geranium, vinca, tomato, and Rieger begonia were fertigated at $100 \mathrm{mg} \cdot \mathrm{L}^{-1} \mathrm{~N}$; whereas chrysanthemum, sunflower, and kalanchoe were fertigated at $200 \mathrm{mg} \cdot \mathrm{L}^{-1} \mathrm{~N}$.

pH data in Expt. 3 indicated that for each measurement date from 7 DAT on, the species showed strongly significantly different responses with monotonically stronger statistical significance on each subsequent measurement date indicating a strong divergence among fertilizer type-concentration treatments (Fig. 3B; Table 1).

There were significant differences in the $\triangle \mathrm{EC}$ over time due to fertilizer type and concentration in Expt. 3. However, the fertilizer type by concentration interaction was not significant (data not shown). The AF had a greater overall mean $\triangle \mathrm{EC}$ than the NF or $\mathrm{BF}$ (Table 3 ). The mean $\triangle \mathrm{EC}$ values for 100 and $200 \mathrm{mg} \cdot \mathrm{L}^{-1} \mathrm{~N}$ were -0.75 and $1.03 \mathrm{dS} \cdot \mathrm{m}^{-1}$, respectively least significant 

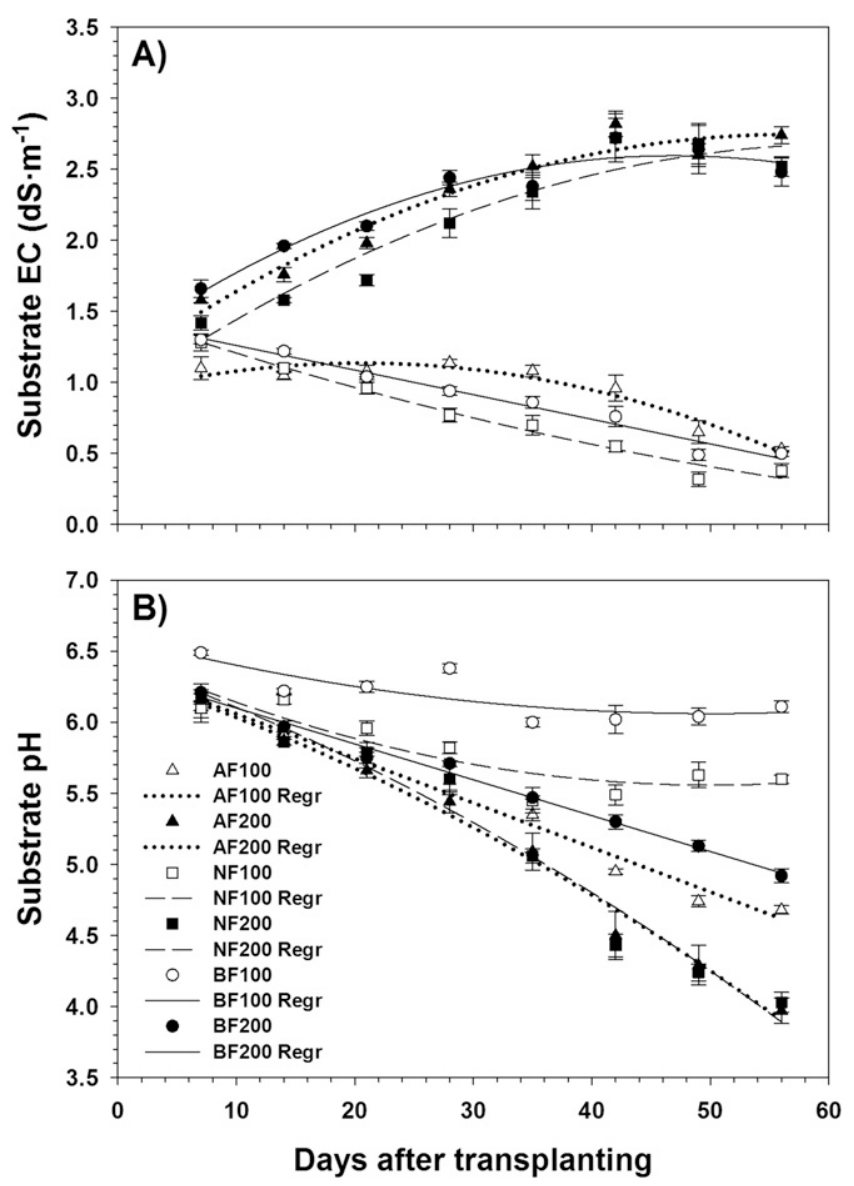

Fig. 3. Mean root substrate (A) electrical conductivity (EC) and (B) pH levels measured from 7 to $56 \mathrm{~d}$ after transplanting for kalanchoe fertilized at each irrigation with acidic (AF), neutral (NF), and basic (BF), water-soluble fertilizers $(20 \mathrm{~N}-4.4 \mathrm{P}-16.6 \mathrm{~K}, 17 \mathrm{~N}-2.2 \mathrm{P}-14.1 \mathrm{~K}$, and $13 \mathrm{~N}-0.88 \mathrm{P}-10.8 \mathrm{~K}$, respectively). Each fertilizer was applied at two concentrations (100 and $\left.200 \mathrm{mg} \cdot \mathrm{L}^{-1} \mathrm{~N}\right)$. The regression (Regr) equations generated for the best fit models were (A) $y_{\mathrm{AF} 100}=0.924+0.0205 x-0.000496 x^{2}\left(r^{2}=0.83\right)$, $y_{\mathrm{AF} 200}=1.12+0.0576 x-0.000510 x^{2}\left(r^{2}=0.89\right), y_{\mathrm{NF} 100}=1.47-0.0282 x+0.000136 x^{2}\left(r^{2}=94\right), y_{\mathrm{NF} 200}=$ $0.920+0.0568 x-0.000459 x^{2}\left(r^{2}=0.81\right), y_{\mathrm{BF} 100}=1.43-0.0173 x\left(r^{2}=0.93\right)$, and $y_{\mathrm{BF} 200}=1.27+0.0567 x-$ $0.000605 x^{2}\left(r^{2}=0.80\right)$ and (B) $y_{\mathrm{AF} 100}=6.37-0.0314 x\left(r^{2}=0.94\right), y_{\mathrm{AF} 200}=6.33-0.0272 x-0.000290 x^{2}$ $\left(r^{2}=0.95\right), y_{\mathrm{NF} 100}=6.47-0.0366 x+0.000367 x^{2}\left(r^{2}=0.72\right), y_{\mathrm{NF} 200}=6.42-0.0288 x-0.000292 x^{2}$ $\left(r^{2}=0.95\right), y_{\mathrm{BF} 100}=6.59-0.0212 x+0.000211 x^{2}\left(r^{2}=0.61\right)$, and $y_{\mathrm{BF} 200}=6.35-0.252 x\left(r^{2}=0.95\right)$. Bars indicate \pm SE $(\mathrm{n}=5)$.

Table 3. Effects of fertilizer type on the change $(\Delta)$ in mean root substrate electrical conductivity (EC) and fertilizer type and concentration on the change $(\Delta)$ in mean root substrate $\mathrm{pH}$ of kalanchoe from 7 to $56 \mathrm{~d}$ after transplanting in Expt. 3.

\begin{tabular}{|c|c|c|c|}
\hline \multirow[b]{2}{*}{ Fertilizer type } & \multirow[b]{2}{*}{$\Delta \mathrm{EC}\left(\mathrm{dS} \cdot \mathrm{m}^{-1}\right)$} & \multicolumn{2}{|c|}{$\Delta \mathrm{pH}$} \\
\hline & & $100 \mathrm{mg} \cdot \mathrm{L}^{-1} \mathrm{~N}$ & $200 \mathrm{mg} \cdot \mathrm{L}^{-1} \mathrm{~N}$ \\
\hline Acidic (20N-4.4P-16.6K) & 0.30 & -1.41 & -2.14 \\
\hline Neutral $(17 \mathrm{~N}-2.2 \mathrm{P}-14.1 \mathrm{~K})$ & 0.10 & -0.50 & -2.14 \\
\hline Basic $(13 \mathrm{~N}-0.88 \mathrm{P}-10.8 \mathrm{~K})$ & 0.01 & -0.38 & -1.29 \\
\hline $\operatorname{LSD}_{0.05}{ }^{\mathrm{z}}$ & 0.16 & & \\
\hline
\end{tabular}

LSD $=$ least significant difference.

${ }^{\mathrm{z}} \mathrm{LSD}$ values for $\triangle \mathrm{EC}$ are for comparing between fertilizer types. LSD values for $\Delta \mathrm{pH}$ are for fertilizer concentrations for a given fertilizer type or fertilizer types for a given fertilizer concentration.

difference $\left(\operatorname{LSD}_{0.05}=0.13\right)$. This indicated insufficient fertilizer supply at the lower concentration. This was further supported by Fig. 3A, which shows substrate EC levels for the three $100 \mathrm{mg} \cdot \mathrm{L}^{-1} \mathrm{~N}$ treatments were characterized by a slow, steady decline reaching low levels of 0.38 to $0.52 \mathrm{dS} \cdot \mathrm{m}^{-1}$ at $56 \mathrm{DAT}$. Whipker et al. (2001) reported that the recommended pourthrough extract EC range for kalanchoe is 2.0 to $3.5 \mathrm{dS} \cdot \mathrm{m}^{-1}$. All three fertilizers at $200 \mathrm{mg} \cdot \mathrm{L}^{-1} \mathrm{~N}$ in Expt. 3 rose into this range by 28 DAT.
There was a significant fertilizer type by concentration interaction for $\mathrm{pH}$ in Expt. 3. The overall effect showed the AF lowered the $\mathrm{pH}$ more than $\mathrm{NF}$ and $\mathrm{BF}$ at $100 \mathrm{mg} \cdot \mathrm{L}^{-1} \mathrm{~N}$ and the $\mathrm{AF}$ and NF lowered the $\mathrm{pH}$ more than the $\mathrm{BF}$ at $200 \mathrm{mg} \cdot \mathrm{L}^{-1} \mathrm{~N}$ (Table 3). Patterns of substrate $\mathrm{pH}$ decreases associated with the three fertilizers at the lower concentrations treatments are illustrated in Fig. 3B. Treatment AF100 resulted in a linear $\mathrm{pH}$ decline from 6.09 to 4.68 at $56 \mathrm{DAT}$. The potentially neutral, NF100 solution was associated with a smaller $\mathrm{pH}$ decline from 6.10 to 5.60 . Substrate $\mathrm{pH}$ in the potentially basic, BF 100 treatment began at 6.49 , declined to a minimum level around 42 DAT, and then increased ending at 6.11 at 56 DAT. The PABRs for these $\mathrm{AF}, \mathrm{NF}$, and $\mathrm{BF}$ were expressed in the final substrate $\mathrm{pH}$ levels of $4.68,5.60$, and 6.11 , respectively.

Substrate $\mathrm{EC}$ and $\mathrm{pH}$ responses to the $200 \mathrm{mg} \cdot \mathrm{L}^{-1} \mathrm{~N}$ fertilizer treatments were very different. EC increased to levels of 2.72 to 2.82 $\mathrm{dS} \cdot \mathrm{m}^{-1}$ at 42 DAT (Fig. 3A). After that time, the EC remained relatively constant. This suggested above-adequate fertilizer application to 42 DAT followed by application in balance with demand. Substrate $\mathrm{pH}$ declined continuously throughout the experiment in the three treatments (Fig. 3B). Responses to the potentially $\mathrm{AF}$ and NF were similar, with the final $\mathrm{pH}$ of $\approx 4.0$. The $\mathrm{BF}$ resulted in a linear $\mathrm{pH}$ decline to a low value of 4.92 .

The PABRs of the fertilizers were most closely correlated with change in substrate $\mathrm{pH}$ when the $100 \mathrm{mg} \cdot \mathrm{L}^{-1} \mathrm{~N}$ concentration was applied. Substrate EC levels in these treatments indicated inadequate nutrition, thus a high proportion of fertilizer provided was taken up by plants. Under this condition, the biotic fertilizer effect (the PABR) was strong relative to the abiotic effect. The biotic effect with fertilizer treatment BF100 counteracted the abiotic acidity effect of the fertilizer to a stronger degree than with NF100, as was expected. The acidic biotic effect of fertilizer treatment AF100 enhanced the abiotic effect as seen in the rapid decline in substrate $\mathrm{pH}$ throughout the $56 \mathrm{~d}$. Accumulation of fertilizer salts in substrate of the $200 \mathrm{mg} \cdot \mathrm{L}^{-1} \mathrm{~N}$ series of fertilizer treatments, as seen in rising substrate EC levels, resulted in the biotic fertilizer effect being proportionately smaller than the abiotic effect on substrate $\mathrm{pH}$. This relationship of declining substrate $\mathrm{pH}$ with rising fertilizer concentration has been reported by Fisher et al. (2014b). Consequently, all substrate $\mathrm{pH}$ values were lower in this fertilizer series than in the $100 \mathrm{mg} \cdot \mathrm{L}^{-1} \mathrm{~N}$ series. The basic BF200 fertilizer treatment had the highest $\mathrm{pH}$ values in the $200 \mathrm{mg} \cdot \mathrm{L}^{-1} \mathrm{~N}$ series. Substrate $\mathrm{pH}$ in this treatment did not plateau as in BF100, but continued to decline to a value of 4.92 compared with 6.11 in the BF100 treatment. The biotically neutral effect of NF200 fertilizer treatment was insufficient to counteract the abiotic fertilizer acidity effect, thus $\mathrm{pH}$ declined continuously.

The acidic abiotic effect of fertilizers is due in part to the acidity of the compounds making up the fertilizer solution. However, this does not explain all of the acidic effect since the solution $\mathrm{pH}$ of the high concentration acidic PABR fertilizer in this study (6.02) was higher than that of the NF (4.55) and $\mathrm{BF}$ (5.82). Influence of fertilizer cations on substrate cation exchange sites plays a major role (Fisher et al., 2014b). Alkaline PABR fertilizers typically have a higher $\mathrm{Ca}^{2+}$, and possibly $\mathrm{Mg}^{2+}$, but lower $\mathrm{NH}_{4}^{+}$content than acidic PABR fertilizers. Due to a higher affinity of divalent than monovalent ions for 
exchange sites, alkaline PABR fertilizer displaces more protons into the bulk solution than acidic PABR fertilizer. An initial decrease in $\mathrm{pH}$ can occur. But, this is rapidly replaced with a $\mathrm{pH}$ increase when displaced protons are leached by watering and fertilization, giving way to a lower bulk solution proton concentration in equilibrium with the lower proportion of protons on exchange sites.

In Table 3, it is apparent that the $\Delta \mathrm{pH}$ value for kalanchoe declined from -2.14 to -0.50 , a shift from the large to small acidification categories, when NF concentration was reduced. This indicates the large role that fertilizer concentration played in acidification. It further suggests that fertilizer concentration could have played a role in the species differences measured in Expts. 1 and 2. Highly efficient fertilization and nutritional monitoring practices have not been developed for every crop. It is conceivable that across the species in this study, nutritional availability levels ranged from just sufficient to various levels moderately above sufficiency. This would have altered the balance between abiotic and biotic fertilizer influences confounding the species effect with the fertilizer concentration effect. This factor is present in commercial production as well, since multiple crops must be grouped into each of a limited number of fertilization programs to comply with physical equipment and economic constraints.

\section{Conclusions}

Commercially important differences in substrate $\mathrm{pH}$ occurred across the 13 plant species. This suggests the need to categorize greenhouse crops according to their association with substrate $\mathrm{pH}$ when developing fertilization programs. It further indicates a need in commercial production to analyze the substrate separately for these categories of crops for better management of $\mathrm{pH}$. Expression of the current predicted PABRs assigned to fertilizers depends on the proportion of applied fertilizer taken up by the crop. Basic and neutral reaction fertilizers can have an acidic effect on substrate when applied to crops in high quantity. This calls attention to the importance of monitoring substrate EC as a tool for regulating fertilizer application in accordance with crop demand. Furthermore, this justifies the value of understanding fertilizer use efficiency for implementation of best management practices.

\section{Literature Cited}

Argo, W.R. 1996. Root zone pH, calcium and magnesium management in peat-based container media. PhD Diss., Michigan State Univ., East Lansing, MI.

Argo, W.R., V.J. Weesies, E.M. Bergman, M. Marshal, and J.A. Biernbaum. 1997. Evaluating rhizon soil solution samplers as a method for extracting nutrient solution and analyzing media for container-grown crops. HortTechnology 7:404-408.

Association of Official Analytical Chemists (AOAC). 1970. Official methods of analysis. 11th ed. AOAC International, Washington, DC.

Association of Official Analytical Chemists (AOAC). 1999. Official methods of analysis. 16th ed. AOAC International, Gaithersburg, MD.

Bailey, D.A. 1996. Alkalinity, pH, and acidification. In: D.W. Reed (ed.). A grower's guide to water, media, and nutrition for greenhouse crops. Ball Publishing, Batavia, IL.

Fisher, P.R., W.R. Argo, and J.A. Biernbaum 2014a. Validation of a fertilizer potential acidity model to predict the effects of watersoluble fertilizer on substrate $\mathrm{pH}$. HortScience 49:1061-1066.

Fisher, P.R., R.W. Dickson, G.S. MohammadPour, and J. Huang. 2014b. Effect of solution electrical conductivity (EC) and pre-plant nutrient form on the $\mathrm{pH}$ of a peat-perlite substrate. Acta Hort. 1034:249-254.

Hanson, E.J. 2006. Nitrogen fertilization of highbush blueberry. Acta Hort. 715:347-352.

Havlin, J.L., S.L. Tisdale, W.L. Nelson, and J.D. Beaton. 2014. Fertility and fertilizers: Introduction to nutrient management. 8th ed. Pearson/ Prentice Hall, Upper Saddle River, NJ.

Hignett, T.P. 1985. Physical and chemical properties of fertilizers and methods for their determination, p. 284-316. In: T.P. Hignett (ed.). Fertilizer manual. Springer, The Netherlands.

Huang, J., P.R. Fisher, W.E. Horner, and W.R Argo. 2010. Limestone particle size and residual lime concentration affect $\mathrm{pH}$ buffering in container substrates. J. Plant Nutr. 33(6):846858.

Huang, J.S., P.V. Nelson, and J.W. Lee. 2001. Seedling effect on root substrate $\mathrm{pH}$. J. Plant Nutr. 24:1133-1147.
Johnson, C.N., P.R. Fisher, J. Huang, R.P. Vetanovetz, and W.R. Argo. 2010. Quantifying the acidity of an ammonium-based fertilizer in containerized plant production. HortScience 45:10991105.

Johnson, C.N., P.R. Fisher, J. Huang, T.H. Yeager, T.A. Obreza, R.P. Vetanovetz, W.R. Argo, and A.J. Bishko. 2013. Effect of fertilizer potential acidity and nitrogen form on the $\mathrm{pH}$ response in a peat-based substrate with three floricultural species. Sci. Hort. 162:135-143.

Kafkafi, U. 2008. Functions of the root system. In: M. Raviv and J. Heinrich Lieth (eds.). Soilless culture: Theory and practice. Elsevier Science, Boston, MA.

Marschner, H. 1995. Mineral nutrition of higher plants. 2nd ed. Elsevier, New York, NY.

Nelson, P.V. 2011. Fertilization, p. 261-318. In P.V. Nelson (ed.). Greenhouse operation and management. 7th ed. Prentice Hall, Upper Saddle River, NJ

Pertusatti, J. and A.G.S. Prado. 2007. Buffer capacity of humic acid: Thermodynamic approach. J. Colloid Interface Sci. 314:484-489.

Pierre, W.H. 1933. Determination of equivalent acidity and basicity of fertilizers. Ind. Eng. Chem. 5:229-234.

Rippy, J.F.M., P.V. Nelson, D.L. Hesterberg, and E.J. Kamprath. 2007. Reactivity rates of twenty limestones. Commun. Soil Sci. Plant Anal. 38(13-14):1775-1783.

Rippy, J.F.M., P.V. Nelson, D.L. Hesterberg, C.E. Niedziela, Jr., E.J. Kamprath, and T. Bilderback. 2016. Importance of limestone specific surface for assessing neutralization effectiveness in soilless root substrate. Commun. Soil Sci. Plant Anal. 47(4):521-526.

Taiz, L. and E. Zeiger. 2010. Plant physiology. 5th ed. Sinauer Associates, Sunderland, MA

Taylor, M.D., P.V. Nelson, J.M. Frantz, and T.W. Rufty. 2010. Phosphorus deficiency in Pelargonium: Effects on nitrate and ammonium uptake and acidity generation. J. Plant Nutr. 33(5):701-712.

von Wirén, N., S. Gazzarrini, and W.B. Frommer. 1997. Regulation of mineral nitrogen uptake in plants. Plant Soil 196(2):191-199.

Whipker, B.E., J.M. Dole, T.J. Cavins, J.L. Gibson, W.C. Fonteno, P.V. Nelson, D.S. Pitchay, and D.A. Bailey. 2001. Plant root zone management North Carolina Commercial Flower Growers' Association, Raleigh, NC.

Zhu, Y.Y., T.J. Di, G.H. Xu, X. Chen, H.Q. Zeng, F. Yan, and Q.R. Shen. 2009. Adaptation of plasma membrane $\mathrm{H}+$-ATPase of rice roots to low $\mathrm{pH}$ as related to ammonium nutrition. Plant Cell Environ. 32:1428-1440. 